Article

\title{
The 'Arc of Prosperity' Revisited: Homelessness Policy Change in North Western Europe
}

\author{
Isobel Anderson ${ }^{1}$, Evelyn Dyb ${ }^{2, *}$ and Joe Finnerty ${ }^{3}$ \\ ${ }^{1}$ Faculty of Social Sciences, University of Stirling, Stirling, FK9 4LA, UK; E-Mail: isobel.anderson@stir.ac.uk \\ 2 Urban and Regional Research Institute, Oslo and Akershus University College, 0130 Oslo, Norway; \\ E-Mail: evelyn.dyb@nibr.hioa.no \\ ${ }^{3}$ School of Applied Social Studies, University College Cork, Cork, Ireland; E-Mail: j.finnerty@ucc.ie \\ * Corresponding author
}

Submitted: 24 May 2016 | Accepted: 5 September 2016| Published: 20 October 2016

\begin{abstract}
This paper compares continuity and change in homelessness policy in Ireland, Scotland and Norway with a particular focus on the period of post-crisis austerity measures (2008-2016). The analytical approach draws on institutional theory and the notion of path dependency, which has rarely been applied to comparative homelessness research. The paper compares welfare and housing systems in the three countries prior to presenting a detailed analysis of the conceptualisation and measurement of homelessness; the institutions which address homelessness; and the evidence of change in the post-2008 period. The analysis demonstrates that challenges remain in comparing the nature of homelessness and policy responses across nation states, even where they have a number of similar characteristics, and despite some EU influence towards homelessness policy convergence. Similarly, national-level homelessness policy change could not be interpreted as entirely a result of the external shock of the 2008 general financial crisis, as existing national policy goals and programmes were also influential. Overall, embedded national frameworks and institutions were resilient, but sufficiently flexible to deliver longer term policy shifts in response to the changing nature of the homelessness problem and national policy goals. Institutionalism and path dependency were found to be useful in developing the comparative analysis of homelessness policy change and could be fruitfully applied in future longitudinal, empirical research across a wider range of countries.
\end{abstract}

\section{Keywords}

homelessness; institutionalism; path dependency; policy change

\section{Issue}

This article is part of the issue "Homelessness and Social Inclusion", edited by Isobel Anderson (University of Stirling, UK), Maša Filipovič Hrast (University of Ljubljana, Slovenia) and Joe Finnerty (University College Cork, Ireland).

(C) 2016 by the authors; licensee Cogitatio (Lisbon, Portugal). This article is licensed under a Creative Commons Attribution 4.0 International License (CC BY).

\section{Introduction}

"We believe that Scotland can match the success of similar countries-Ireland to our west, Iceland to our North and Norway to our east, nations that sit at the top of world wealth league tables and form an arc of prosperity around our shores." (Scottish Government, 2007, p. 9)
This ambitious vision on the part of the Scottish Government pre-dated the global financial crisis (GFC) which commenced with the 2008 credit crunch and continued to affect all four countries mentioned to varying degrees. The quotation was also a point of departure for an earlier comparative analysis of homelessness policy in Ireland, Scotland and Norway (Anderson, Dyb, \& Finnerty, 2008). Subsequently, the financial crisis hit large parts of Europe, with the implementation of austerity policies as 
national governments sought to address the impact of the crisis via contractionary fiscal policies.

Building on our earlier comparative analysis, this article explores whether and how homelessness policy changed in this economically challenging period, framed within theories of path dependency regarding welfare and housing systems, as well as homeless-specific policies. Prior to the GFC, the three countries exhibited some similarity in homelessness problems and policies (e.g. convergence on housing-led approaches to homelessness), despite being dissimilar in other aspects of homelessness governance, housing systems and welfare regimes. Given the differing nature and severity of how the GFC manifested and was responded to in the three countries, the paper explores whether this resulted in increasing divergence in homelessness policies and in the nature and scale of homelessness since 2008.

The three countries considered here were differently affected by the crisis: Ireland as one of the hardest hit countries in Europe, Scotland less so, and Norway with hardly any noticeable changes to the economy during the period in question. Though hardest hit by the crisis, Ireland responded as the 'model pupil' in relation to complying with the demands of the EU Troika programme (which provided aid through the European Commission, the European Central Bank and the IMF to Ireland and four other countries, Pisany-Ferry, Sapir, \& Wolff, 2013) and implemented policies which prioritised cutbacks in capital expenditure programmes such as social housing construction (Dukelow, 2016). While the devolved nature of Scottish government makes it appropriate to consider Scotland as a distinct nation in relation to housing policy and responses to homelessness (McKee, Muir, \& Moore, 2016), Scotland experienced severe cuts to public expenditure and welfare services as part of the UK response to the GFC, particularly in the post-2010 period (Lupton, Burchardt, Hills, Stewart, \& Vizard, 2016), even though the UK avoided any troika 'bail out'. Due to a solid oil-based economy, Norway was largely shielded from the effects of the crisis until as recently as late 2015, although a sharp drop in oil prices at an early stage of the crisis created uncertainty in the oil dependent part of the economy. By 2016, investments in oil production and oil related activities were in a phase of rapid downsizing, with widespread consequences, in particular for the Western coastline of Norway with a rather dramatic increase in unemployment.

The connections between homelessness, wider societal structures and events such as the global financial crisis are complex. Although a detailed critique of the impact of the GFC on Ireland, Scotland and Norway is beyond the scope of this paper, it is possible to examine whether and how homelessness policies developed and changed during the subsequent period of profound economic and social change in Europe. In contrast, the immediate prior period (2000 to 2007), had been largely characterised by prosperity and a degree of convergence in progressive, inclusive homelessness policies, particu- larly embracing housing-led approaches, in and beyond our three countries (Anderson et al., 2008; Benjaminsen, Dyb, \& O'Sullivan, 2009).

Our key research question then is whether and how homelessness policy changed across the three countries in the more economically challenging period after the GFC. Section 2 sets out our analytical approach to the question and our research method. Our comparison of welfare regimes and social housing systems is further developed in section 3 . In section 4 we revisit the conceptualisation and measurement of homelessness in the three countries and the nature of the institutions which deliver homelessness policies and responses, before examining change in the post-2008 period. Taking account of differences in conceptualisation and measurement in the three countries, we examine whether there were changes in the nature of homelessness in the post-2008 period and what were the resultant policy challenges in sustaining a housing-led focus on resolving homelessness. Our analysis of homelessness in relation to notions of path dependency and institutional embeddedness enables development of our final comparative analysis and conclusions on homelessness policy continuity and change across the three countries (Sections 5 and 6).

\section{Analytical Model and Research Method}

Our analytical approach draws on institutional theory and the notion of path dependency. This approach is well suited to compare cases that share some overall features, however divergent in specific areas. Although the 'arc of prosperity' phrase seemed of limited validity in retrospect, the three countries continued to share some key characteristics which suggested they remained reasonably comparable with each other as case study examples (Yin, 1994). They are sited within the Northern arc of Europe and geographically at the fringe of the European Union. Ireland and Scotland/the UK are EU members (the research was completed prior to the 2016 UK referendum on EU membership) and although Norway is not a member of the EU, its economy is deeply woven into EU legislation and the wider economy of the European Economic Area (EEA). The countries have similar populations, ranging from just above 4.8 million inhabitants in Ireland, to 5.2 million in Scotland, with Norway in a middle position with just above 5 million inhabitants. They are all 'mature' welfare states with well-established welfare institutions, and included both as 'Northern European' countries and as 'high-income' countries in the United Nations (2015) classification of countries by major areas/region of the world. Comparing the three economies is complicated by the inclusion of Scotland within the larger UK economy with a population of 60 million (Figure 1). Scotland (UK)'s GDP has been consistently lower than that of Ireland, with Norway significantly more prosperous than the other two countries, though all three remained above the EU average GDP before and after the GFC. 


\section{GDP per capita}

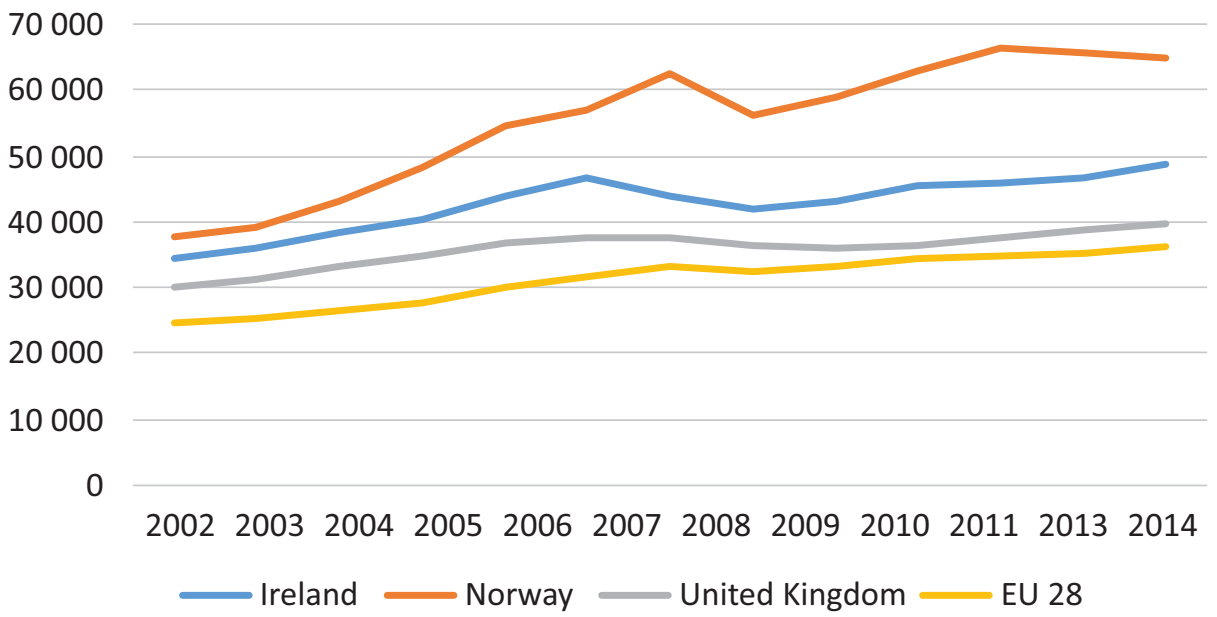

Figure 1. GDP per capita for the three countries and EU average. Source: OECD http://ec.europa.eu/eurostat/web/nationalaccounts/data/database (Scotland represented by UK figures).

Our comparison of the three countries is derived from desk-based research by the three authors drawing on the international research literature and publicly available official statistics and policy documentation for the three countries. The research method incorporated application of our theoretical approach to the comparative review of the evidence of continuity or change in homelessness and policy responses in our three case study countries. While other studies (e.g. Fitzpatrick \& Stephens, 2014) have benefited from crossnational empirical data collection, this article focuses on change over time, utilising the existing data sets for the three countries.

Our theoretical approach draws on the notion of path dependence and institutional theory (Mahoney, 2000; North, 1990). That is to say, what are the conditions for emergence of institutions, for sustaining institutions and for institutional changes? The notion of path dependency does not predict a deterministic process, 'it is not a story of inevitability in which the past neatly predicts the future' (North, 1990). There might be, and usually are, several events influencing any one event, decision, policy programme etc., some of which perhaps lead to unintended results or to the final result (intended or unintended). The decisions made at one point in the historical pathway are likely to narrow the choices at a later point. However, while the main institutions in society may be solid and only change slowly, at a particular moment striking turns may occur or be activated, for example involving sudden economic shocks such as the GFC. These possible turns or developments are, however, dependent on and limited by former developments and structures.

The development of the divergent housing systems in the Nordic countries was rigorously investigated by Bengtsson, Annaniassen, Jensen, Ruonavaara and Sveinsson (2006) and Bengtsson and Rounavaara (2010) who argued that path dependency allowed for the possibility that single events might influence societal outcomes, but also that previous events might be distant in time from the outcomes explained by them. Importantly, explanation required a process or 'temporal' approach, analysing change over time: 'progress in the analysis of social, institutional and discursive change in housing...lies in combining historical and contextual sensitivity with a thinking in terms of social mechanisms' (p. 200). Discussing homelessness in relation to institutionalism and path dependency is rare in the European research literature on homelessness, though Irving-Clarke (2016) applied this framework to his analysis of policy development for supported housing in the UK. This paper seeks to contribute to the literature on homelessness and social inclusion by taking forward the longitudinal analysis of institutionalism, path dependency and homelessness. Figure 2 shows a simplified diagram of our analytical model relating institutional structures and path dependence to an analysis of homelessness policy.

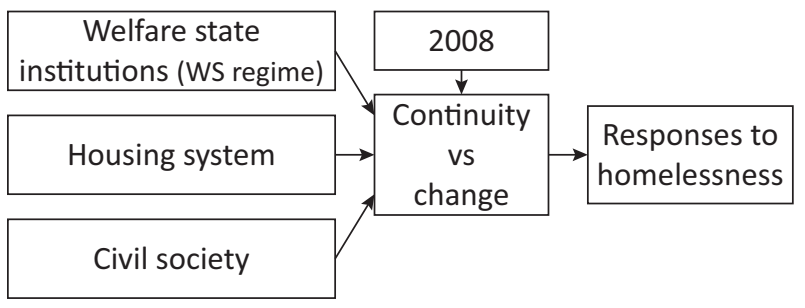

Theoretical approach: Path dependende

Figure 2. Institutional structures influencing homelessness policy change (source: authors).

Path dependency is the analytical concept of the model. From left to right, Figure 2 shows three sets of variables (welfare state institutions, the housing system and civil society) which to a larger or smaller degree in different national settings influence policy responses to homelessness. The welfare state institutions comprise the most 
comprehensive set of variables and cover all types of institutions involved in homeless policy in a broad sense. Esping-Andersen's (1990) typology of welfare regimes serves as a concept to narrow and handle the welfare state institutions. The relationship between the welfare system and the housing system is complicated (section 3 below). Stephens, Fitzpatrick, Elsinga, van Steen and Chzhen (2010) found welfare systems to be a vital factor in explaining levels of homelessness and interventions within nation states, but they also emphasised that the housing system and housing policies are important influences. Within civil society, voluntary organisations are particularly important players in the homelessness field, although their role varies across the three countries in this article. Private providers of homelessness services might also be included within the civil society set of variables, depending on the nature of their involvement in welfare arrangements to tackle homelessness. The 2008 point marks the onset of the GFC which was followed by a period of austerity politics, which may or may not trigger changes in responses to homelessness. The institutional arrangements covered by the independent or explanatory variables will also have developed along certain paths, with vital decisions taken at certain points in time. While it is important to acknowledge that 'politics matters' in the analytical frame of path dependency, selected policy alternatives are likely to depend on prior events and choices.

Delving into each of the three sets of variables in detail is beyond the scope of this article. Rather, our ambition is to shed light on how homelessness and policy responses were shaped by the footprints of the welfare and housing institutions in the three countries and to examine the responsiveness of institutions to austerity policy after 2008. For example, path dependence would suggest a preliminary hypothesis that policy reactions to increased risks of structural homelessness and associated changes in the profile of the homeless population would reflect both prior policy arrangements and some degree of institutional inertia, particularly in relation to social housing supports. Regarding the comparative aspect, DiMaggio and Powell (1991) argues that modern institutions tend to develop towards isomorphism and convergence. Processes and initiatives at EU level, such as the Open Method of Coordination, peer reviews of homelessness strategies across the EU members, and work by FEANTSA [European Federation of National Organisations Working with the Homeless] (the umbrella organisation for European organisations working with homelessness) to coordinate policy and research across the EU may also have driven convergence rather than differentiation (Gosme, 2014; Gosme \& Anderson, 2015).

\section{The Welfare State and Social Housing}

Approaches to the comparative analysis of social policy, including housing and homelessness, have developed substantially since the ground breaking work of
Gøsta Esping-Andersen (1990) which set out the thesis of three distinct, path dependent models of welfare capitalism (universalistic, corporatist and liberal). Criticisms have included neglecting the position of women (Sainsbury, 1999) as well as the role of housing systems. Esping-Andersen's analysis did not incorporate the Southern European nations and was completed before the post-communist Eastern European nations became integrated into European social policy, but scholars have subsequently sought to address these issues (e.g. Deacon, 2000; Ferrera, 1996; Gal, 2010). Our three countries diverge in their welfare state regime categorisation. Ireland and Scotland belong to the liberal welfare state model while Norway is an archetype of the social democratic (universal) welfare state. However, while accurately placed in the liberal model over many policy areas, Ireland had, up until the early 1990s, conformed to a more social democratic approach in some areas of housing, involving a lead role by local authorities in social housing provision (Finnerty, 2002; Finnerty \& O'Connell, 2014a; Kenna, 2011). Similarly, Anderson (2004) argued that Scotland had more social-democratic roots forged in the 1945-1979 period of welfare and state housing expansion. What is less often noted in discussions of EspingAndersen's welfare state typology is his emphasis on the similarities of modern ( $20^{\text {th }}$ century) welfare state formation. Notably the three countries considered here are all mature welfare states with highly developed welfare arrangements.

While housing has typically been provided through both market and welfare mechanisms, services for homeless people in all three case study countries (shelters, temporary accommodation, day care, soup kitchens/food distribution, etc.) have been the responsibility of welfare services (particularly local authorities, social services, and to a varying degree, the voluntary organisations operating in the field). Housing provision plays a vital role in preventing and counteracting homelessness. The relationship of the housing sector to the welfare state has long been recognised as challenging and complex (Hoekstra, 2010; Kemeny, 1995; Malpass, 2005; Torgersen, 1987) with the housing sector mainly market-driven, even at the height of post-war welfare state provision. However, in parallel with the evolution of welfare states, Governments across Europe have supported the housing sector at certain points in time, in some countries quite heavily (e.g. all the Nordic countries, the UK, the Netherlands and Ireland) even though distinct housing systems developed in different countries. Social housing has been a key element in resolving homelessness and while generally a responsibility of local authorities (social service and/or housing authorities) or voluntary agencies, the development of social/affordable housing is connected to and interwoven with the general housing system.

In Ireland, post-2008 austerity policies initially accelerated the existing policy shift (since 2003) away from traditional local authority housing towards provision by 
housing associations and private landlords renting to tenants in receipt of some form of rental subsidy (eligibility for this means-tested subsidy is determined by the local housing authority.) Central to this policy shift was a deepening reliance on the private market for both the financing and supply of social housing, under the banner of creating the 'flexible and responsive social housing supports' envisaged in the Social Housing Strategy 2020 (DECLG [Department of Housing, Planning, Community and Local Government], 2014, p. 51; Finnerty \& O'Connell, 2014a, 2014b).

However, since 2014, an increasing shortage of affordable accommodation in the private rented sector has cast doubt on the wisdom of reliance on private landlordism in meeting social housing need, especially where policy had embraced housing-led solutions to homelessness. Policy responses to this shortage have included: landlordtenant mediation services (including case-by-case discretionary increase in housing subsidy), more recently followed by an increase in the amount of housing subsidy paid to eligible renters; a two-year rent freeze, and the introduction of a new rental housing subsidy (the Housing Assistance Payment) whose novel feature is a tapered withdrawal of subsidy as household income increases.

Within the UK, Scotland was influential in the $20^{\text {th }}$ century expansion of council housing (and later the housing association sector) both of which provided secure, affordable housing for the working classes. UK-wide policy influenced the subsequent residualisation of council housing through sales to sitting tenants, a policy emphasis on home ownership, and reduced investment in social housing from the 1980s onwards. Like Ireland, Scotland experienced a gradual process of tenure transformation over the long term, where the $21^{\text {st }}$ century saw continuing pressures on social housing, stagnation of home ownership and a resultant resurgence in private sector renting. Scotland's social democratic welfare roots appeared to wither somewhat as income inequality increased in the devolved period (Morelli \& Seaman, 2012). By 2015, while house prices and market rents showed an upward trend, overall housebuilding levels were well below their 2007 peak and social housing completions fell by $44 \%$ from 2010-2014, to just 3,217 in 2014 (Powell, Dunning, Ferrari, \& McKee, 2015). These trends caused significant housing pressures including increased difficulty in entering home ownership. The estimated affordable housing requirement for Scotland was 12,014 dwellings per annum over five years, where the Scottish Government was committed to 6,000 per year in 2011-2016 (Powell et al., 2015).

In contrast to Ireland and Scotland, Norway was known as the social democratic homeowner nation (Annaniassen, 2006), with successive governments since the 1950 s supporting homeownership. The main policy tool was the provision of low interest loans by the State Housing Bank combined with favorable taxation schemes which supported homeownership. According to Annaniassen, the decision to support homeownership was a moment creating a path dependency delimiting the choices of the next generation of politicians and entrepreneurs. In the mid-1980s a conservative government took the decisive step to liberate the housing and financial markets, followed by downscaling of state subsidies to the housing sector. The large sector of cooperative housing had been characterised as a type of solidarity homeownership and, to a certain extent, as social housing. Deregulation led to house price rises in the pure private owner market, and the cooperative sector (still with price regulation) had a strong case when arguing for repealing the regulations. The two sectors became more equal with respect to price and second hand sale (remaining restrictions in the cooperative sector have no impact on price setting). These crucial changes in housing policy affected homelessness policy, or rather, the future basis for homelessness policy. Firstly, the cooperative sector became too expensive for the poorer and more vulnerable households. Secondly, because the cooperative sector was built as a substitute for, and came to a certain extent to replace publicly owned dwellings, these were and remained relatively few in number. Council housing was an important tool in homelessness policy; however due to the shortage of dwellings (just $1.5 \%$ of the total housing stock), it had largely become transitional housing. The policy shift reducing the traditional responsibilities of the Housing Bank might have resulted in a dramatic downsizing of the institution, but, from the end of the 1990s, the Housing Bank became a major national player in social housing policy targeting vulnerable groups. As a vital welfare institution in implementing homelessness policy, the strong position of the Housing Bank also enhanced a housing led homelessness policy at an early stage (around 2000).

Housing systems in Ireland and Scotland historically had some characteristics of a social democratic (rather than a liberal welfare) system, resulting in 'social renting' in these two countries, while the Norwegian housing system developed 'social homeownership'. While momentum for far reaching changes in the structure of the housing systems may be identifiable in all three countries, the specific outcomes were not detached from the preexisting structures in any of them. In all three countries a marked shift towards economic liberalism occurred during the 1980s, continuing through the 1990s and into the $21^{\text {st }}$ century. In the Irish case, the large local authority housing sector was supplemented by housing association provision and from 2003, displacement of this public and housing association provision by private landlords. In Scotland, the late 1980s also marked a long-term shift to privatisation and residualisation of the council housing sector, while in Norway, 'social homeownership' evolved into a 'liberal' system (Stams $\varnothing, 2009,2014)$ with limited public intervention to alleviate the negative effects of the market. Although Ireland saw further reliance on private provision of finance and accommodation supply in the social housing sector in parallel with austerity policy, there was no significant institutional turn in structures for social housing provision directly linked to the GFC in any of the three cases. 


\section{Homelessness, Institutional Embeddedness and Policy Change}

\subsection{Conceptualising Homelessness and Trends in the Homeless Population}

How homelessness is defined in any country directly influences the measurement of homelessness, and the influential ETHOS (European Typology of Homelessness and Housing Exclusion) conceptualisation of homelessness (Edgar, 2009; FEANTSA, 2016) has aided international comparisons. The ETHOS typology identifies four broad conceptual categories (rooflessness, houselessness, insecure housing and inadequate housing) which can be utilised in comparing the definition and measurement of homelessness in Ireland, Scotland and Norway.

In Ireland, homelessness policy continues to understand homelessness as encompassing rooflessness and houselessness only. The official definition remains that of Section 2 of the Housing Act 1988, where a person is regarded as homeless if the housing department of their local authority judges that they have no accommodation that they can 'reasonably occupy', or they are living in some form of emergency accommodation, and are judged to have insufficient resources to secure reasonable accommodation. While this could encompass a wide range of housing need, in practice the definition is interpreted narrowly to focus on those sleeping rough and those living in emergency and transitional accommodation. In the 2008 revised national homelessness strategy, other groups at acute risk of homelessness such as soon-to-be released prisoners without an address were included in the definition DEHLG [Department of the Environment Heritage and Local Government] (2008a). Ireland also conducts national counts of homeless persons. Every three years, Irish local authorities conduct a point in time assessment of homelessness as provided for in section 9 of the Housing Act 1988. The 2008 count enumerated 1394 homeless persons (DEHLG, 2008b, p. 103), although homelessness NGOs disputed these official figures. The local authority three-yearly count has been superseded by a count of rooflessness and houselessness in the five-yearly Census of Population, and more significantly, by a new software system to provide monthly statistics on numbers using emergency shelters only. The most valid and reliable count of rough sleeping has been conducted twice yearly in Dublin since 2007 by the Dublin Regional Homeless Executive. The extent of rough sleeping was relatively low at around 70 persons in Dublin in 2010, predominantly (around 80\%) male and single, with high levels of addiction and mental health issues (O'Reilly et al., 2015). A separate count of those in social housing need, including categories such as living in unaffordable accommodation and involuntarily sharing showed a much larger and growing population, reaching almost 90,000 persons by 2012 .

Homelessness in Ireland is highly concentrated in the main cities, with the Dublin region accounting for $70 \%$ of the recorded houseless population. A significant factor impacting on demand for Irish homeless services prior to the global financial crisis was the growth in homeless persons of Eastern European origin (Bergin, Lawless, Lalor, \& Pym, 2005), resulting from rising unemployment, enlargement of the EU, and the application of a Habitual Residency Condition (which barred anyone not resident in Ireland for the previous two years from claiming social welfare assistance and from eligibility for social housing assistance). From early 2014, houselessness (excluding rough sleepers) increased rapidly, to 6,611 persons nationally $(4,248$ adults and 2,263 dependent children) in August 2016 (DECLG, 2016). This increase is noteworthy for the number of families accommodated in emergency accommodation, involving a $215 \%$ increase in the number of families, and a $215 \%$ increase in the number of children, since July 2014 (DECLG, 2016). In Dublin, the numbers recorded as sleeping rough have fluctuated between 90 and 105 persons in the counts from Spring 2015 to Spring 2016 (DRHE, 2016). Increases in rough sleeping since late 2014 have been recorded by homelessness services in Cork City, with an average of 17 people sleeping rough in August 2016, and a total of 345 people sleeping rough and 124 people in squats throughout 2015 (Cork Simon Community, 2016). Although lagging behind the immediate impact of the 2008 GFC, rising homelessness has been clearly linked to structural/economic (rather than individual level) mechanisms, such as the shortage of available and affordable accommodation in the private rented sector (behind which lies a resumption of rental inflation in the private rental sector for which housing subsidies have failed to compensate; lack of private social housing new build; and policy reliance on private landlords to assume a social housing role) (Finnerty, O'Connell, \& O'Sullivan, 2016; Walsh \& Harvey, 2015). A statutory measure of the 'waiting list' for social housing is an unreliable indicator, as those in certain kinds of rent supplemented accommodation have been removed from the list as being 'adequately housed' in their current private rental accommodation.

For Scotland, the definition of homelessness was consolidated in Section 24 of the Housing (Scotland) Act 1987, and summarised for Government reporting purposes as: 'A person is homeless if he/she has no accommodation in the UK or elsewhere. A person is also homeless if he/she has accommodation but cannot reasonably occupy it, for example because of a threat of violence. A person is potentially homeless (threatened with homelessness) if it is likely that he/she will become homeless within two months.' (Scottish Government, 2008, p. 18). Although superficially similar to the Irish legal definition, Scottish practice embraces elements of all four ETHOS categories (rooflessness, houselessness, insecure housing and inadequate housing) through a wider interpretation of tests of 'reasonableness' of existing or previous accommodation. The legal definition underpins local authority statutory homelessness duties, and official homelessness statistics for Scotland have counted applicants 
who apply to local authorities for assistance under the legislative framework since 1977, resulting in a comprehensive annual data set spanning nearly 30 years. Some 34,662 applications were recorded in the year 2015-16, of which 16,395 were assisted into settled housing, following assessment (Scottish Government, 2016a). For international comparison however, the point in time data on the number of homeless households in temporary accommodation at the end of the annual statistical period is more useful. At 10,555 households on 31 March 2016, this was still significantly higher (pro-rata total population) than the level of homelessness in Ireland. The number of households in temporary accommodation had steadily increased from 3,995 in 2000, to 11,254 in 2011 but this reflected a pre-GFC policy change in the Homelessness etc. (Scotland) Act 2003 which widened the statutory homelessness safety net over the period up to 2012 (Anderson \& Serpa, 2013; Scottish Government, 2015a) rather than the direct or exclusive impact of the GFC. Homeless people who apply for assistance are asked if they have previously slept rough but the Scottish Government has not maintained distinct rough sleeping counts, representing a weakness in the Scottish data on homelessness. However, the Scottish Household Survey indicated rough sleeping was experienced by as many as 5,000 persons a year with around 660 people (mostly men) sleeping rough on a typical night (Fitzpatrick, Pawson, Bramley, Wilcox, \& Watts, 2015). National survey data also confirmed the key role of household-level poverty in the generation of homelessness in Scotland (Fitzpatrick et al., 2015). Over the long term, reasons for homelessness in Scotland have remained closely linked to the breakdown of a relationship or the breakdown of living arrangements in shared accommodation, reflecting a lack of alternative housing availability (Scottish Government, 2015a). The characteristics of homeless applicants were also reported as fairly consistent before and after the GFC: the majority of applicants tend to be single, younger males of White Scottish ethnicity (Scottish Government, 2016a) although the proportion of all applicants reporting needs for support beyond housing increased from $34 \%$ in $2012 / 13$ to $42 \%$ in 2015/16.

Unlike Ireland and Scotland, Norway has no statutory definition of homelessness. Rather, the definition was adopted for research purposes. Inspired by a Swedish national homeless survey in the early 1990s, and informed by the similarities of the two countries' welfare arrangements, Norway adopted the Swedish definition and methods for the first Norwegian homelessness survey. The definition is, as in the Irish case, primarily convergent with the 'roofless' and 'houseless' ETHOS categories. Those counted as homeless in this and future surveys are those without an owned or rented dwelling and staying in one of the following situations: in casual or temporary accommodation, without an organised place of residence for the coming night; and living temporarily with family, friends or acquaintances. Also included are people who are in prison or in an institution, and who are to be released or discharged within two months without an address. Those in precarious housing situations (e.g. moving between short-term tenancies) are not defined as homeless. The Norwegian definition of homelessness may be characterised as rather narrow compared to the legislative driven definition in Scotland, but wider than in countries defining homelessness mainly or exclusively as sleeping rough and staying in homeless shelters. Norway's homelessness census is cross-sectional and measures homelessness during one specific week (usually week 48 or 49). Registration is carried out by service providers (social services, housing authorities, child welfare, correctional services, local and national health services and civil parties). Five homelessness surveys have been conducted since 1996 with the sixth due in late autumn 2016, creating time series data on homelessness in Norway over a period of 20 years (including the 2016 survey), with very little amendment to the definition and operationalisation since 1996. However, the number of variables in the survey was increased successively. The surveys represent a comprehensive picture of homelessness in the country in addition to enumeration of the population. Apart from a drop in the number of homeless people from the first to the second survey, homelessness in Norway has increased slightly with each survey. However, relative to the population growth the increase in homelessness figures were minimal from 2008 to 2012. In 2012 the number enumerated was 6,257, corresponding to 1.27 per 1,000 population (Dyb \& Johannessen, 2013). As also noted by Benjaminsen and Lauritzen (2015) the homeless populations in the Nordic countries are dominated by people with multiple problems. The largest group is single males of national ethnic origin, with an addiction, and with social security benefit as main income. Despite an overall moderate growth in the number of homeless persons, the number of children homeless with their parent(s) increased by $70 \%$ (from 400 in 2008 to 679 in 2012) (Dyb \& Johannessen, 2013), which may reflect a noticeable increase in the number of children living below the EU poverty limit of $26 \%$ from 2008 to 2015 (mainly a structural poverty problem). The 2012 census made an effort to include migrants living on the streets and in night shelters. The objective was only partly successful, not because of the rigid definition of homelessness, but because these groups have very limited rights to welfare services in Norway, and thus are exceptionally hard to reach.

Comparing our three cases, there is no simple correlation between conceptualisation and measurement of homelessness, and either housing system or wider welfare regime, with Ireland and Norway more similar in focusing on rooflessness and houselessness, compared to Scotland's more generous interpretation (including elements of insecure and inadequate housing) which resulted in a higher level of enumerated homelessness. All three countries have collected data on homelessness over the long term and have some post-2008 
data, but differences in definition and frequency of enumeration still preclude straightforward numerical comparisons, though similarities in the profile of homeless households can be identified.

\subsection{Institutions and Homelessness}

Fitting a policy analysis approach, institutions sit below the level of welfare regime types, and include national and local government and other stakeholders governing homelessness (Beer, 2012). Bengtsson and Ruonavaara (2010) highlighted social exclusion and norms of eligibility for access to housing as factors which could contribute to the long term continuity of residential structures. While housing may be largely distributed through the market, homelessness interventions are rarely, if ever, delivered by market mechanisms (though they may reflect market failure). Comparative homelessness research has often used welfare state regimes as a background typology (Anderson \& Ytrehus, 2012; Baptista \& O'Sullivan, 2008; Benjaminsen et al., 2009) and there is some consensus that homelessness to some extent reflects welfare state regimes, the degree of decommodification of welfare and the generosity of welfare spending. Nordic welfare states would be characterised as least commodified/most generous, with the Southern European countries at the opposite end of the spectrum. Stephens et al.'s (2010) comparative study concluded that welfare regimes were of decisive importance for homelessness, although housing systems impacted the risk of becoming homeless. As well as defining homelessness in relation to position in the housing market, homelessness policy often also embraces individual vulnerability. The proportion of people with complex needs in the homeless population is at least partly explained by a low level of poverty and a higher threshold for becoming homeless in the Nordic welfare states compared to countries in the other regime clusters (Stephens et al., 2010). Broadly, the study found that structural homelessness (arising from prevailing social and economic conditions) was lowest where welfare safety nets were strong. The housing market was a major driver of structural homelessness, and access to affordable housing for vulnerable groups was a major concern even in countries with the strongest welfare protection. Targeted interventions could deliver reasonably good outcomes for homeless people, while homeless migrants were often the least well protected group. Drawing on data from the same six-nation study, Fitzpatrick and Stephens (2014) further identified social cohesion and egalitarianism (along with familialism and individualism) as factors influencing interventions and outcomes for vulnerable groups of homeless people. In this section, we examine continuities and changes in the key institutions which provide accommodation and services for homeless people in our case study countries.

In Ireland, the Housing Act 1988 remains the key piece of homelessness legislation, giving power to local authorities to intervene directly via cash payments to homeless persons (e.g. for emergency Bed and Breakfast (B\&Bs)) or by direct provision of social housing (local authority and voluntary providers); or indirectly via cash assistance to voluntary bodies for providing emergency shelters, to assist homeless persons find accommodation. Another housing option is some form of rental housing subsidy, eligibility for which is determined by the housing authority (section 3 above). However, the 1988 Act left unclarified the relations between local authorities and the other statutory provider, the Health Boards (subsequently the Health Services Executive), and indeed with voluntary providers. The Housing Act gave considerable discretion to local authorities in terms of who was to be counted as homeless and what services were to be provided to them, while the Health Service Executive continues to have a broadly defined remit to meet the needs of homeless persons. The strong position of the church in Ireland has also been emphasised with respect to homeless policies (Baptista \& O'Sullivan, 2008). This position has played out at a number of levels: in terms of the mixed economy of welfare, a strong reliance on charities (albeit now with quite high levels of state funding) to provide emergency responses; in attitudinal terms, a relatively high level of public support for tackling homelessness (in the abstract); and-in the face of loss of trust in a variety of institutions (including charities) - a continuing high level of public goodwill towards organisations providing services for, and advocating policy change in relation to, homelessness (Finnerty, 2014a, 2014b).

In Scotland, local authorities also emerged as state providers of housing and also became the institutional solution to homelessness from the introduction of the legal framework in for England and Scotland in 1977. An important difference from the Irish case is that Scottish legislation conveys statutory duties to assist certain households facing homelessness, rather than merely discretionary powers to intervene. By and large, up to the end of the 20th century, Scottish households who applied and were eligible for assistance were rehoused in secure council or housing association tenancies. However, the legislation worked least well for single people and couples without children, who were largely excluded from the benefits of the legislation as 'not in priority need'. The institutional role for local authorities was expanded in Scottish legislative change in the $21^{\text {st }}$ century, with the abolition of the 'priority need test' by the end of 2012 effectively enhancing the strong legal framework, so that all applicants assessed as unintentionally homeless were entitled to settled accommodation (Anderson \& Serpa, 2013). Institutionally, local authorities are assisted in their homelessness duties by third sector housing associations, advocacy agencies and support service providers, as well as by welfare policy (through UK and Scottish government health and social security services and local social care authorities), reflecting the dual requirement for both a housing policy and welfare policy solution to homelessness. 
Although Norway has no homelessness legislation, the right to a roof over your head and to receive assistance with acquiring a permanent dwelling is legislated for in the Social Services Act, and institutionally embedded in welfare provision nationally in the Ministry of Social Affairs and locally by the municipal social services authorities. Homelessness policy is shaped and implemented by and between the institutional spheres of the national housing authority, which has no real counterpart at the municipal level, and the social welfare authorities both nationally and locally. Embeddedness of homeless policy within the national housing authority (the Housing Bank) has secured a steady focus on access to housing as an objective to counteract and alleviate homelessness. However, policy tools are limited, comprising targeted economic support and soft measures like programmes accompanied by support for developing competence and guidance. Local authorities exercise extensive autonomy in welfare service delivery, whereas social housing, with a weak legal status, varies widely between municipalities. The voluntary sector is an important stakeholder, however its role as advocate for homeless people is of greater importance than its share of total homeless service provision.

Looking at homelessness institutions in our three case study countries, we can see that core housing and welfare institutions have displayed considerable embeddedness since the post-world war II growth of the welfare state. Ireland and Scotland are most similar due to the institutional role of local authorities and housing associations in providing affordable rented housing, with Norway displaying a degree of institutional change in the role of the State Housing Bank in developing and implementing homelessness policy. The increasing role for voluntary sector institutions in homelessness advocacy and service provision has been identified in all three countries, albeit often in partnership with the state sector.

\subsection{Homelessness After the 2008 Financial Crisis-Policy Change in Three Case Study Countries}

In this section of the paper, we examine whether key policy shifts in homelessness occurred in the post-2008 austerity period, despite institutional embeddedness of housing systems and institutionalised homelessness structures. Given that the GFC was more directly associated with austerity policy in the two liberal welfare states, compared to the more economically resilient social democratic welfare state, we consider whether there has been associated divergence in homelessness and policy responses.

In relation to housing and housing policy in Ireland, a very sharp decrease in funding available for social housing construction occurred after 2008. However, the GFC merely intensified an existing trend, visible since 2003, toward increased reliance on the private rented sector to meet social housing need, via both leasing and housing subsidy arrangements (Finnerty et al., 2016). While this planned private provision of the social housing 'offer' was clearly inferior to the housing offer from local authorities and housing associations in relation to security of tenure, the principal problem continued to be the lack of participation by private landlords in these leasing and subsidy arrangements. Nonetheless, the three governments in power over this period remained committed to tackling homelessness and increasing social housing output in response to the wider context of growing housing insecurity amongst low-income households in the private rented and in owner-occupied tenures (including those in long-term mortgage arrears). The 'partnership government' of May 2016 created a new Department of Housing, and the new Minister of Housing rapidly produced an Action Plan for Housing and Homelessness which, inter alia, provides incentives to private landlords to participate in social housing delivery and accelerates the resumption of social housing construction by local authorities and housing associations (with a target of 47,000 new units by 2021 (Government of Ireland, 2016). In relation to homelessness, the national homelessness policy, published in 2008 just as the housing bubble was bursting, had as its key target the elimination of long term homelessness by end 2010 (DEHLG, 2008a). When this target was not met, and despite the backdrop of economic crisis, the target was restated briefly in the context of a 2011 housing policy statement by the incoming coalition government, and elaborated on in a 2013 homelessness policy statement (with 2016 as the revised target year for ending homelessness) (DE$C L G, 2013)$. A further significant intervention was the requirement placed on the main urban local authorities to prioritise homeless households in their allocations policies. While the Action Plan omits mention of the elimination of homelessness, it nonetheless lists a series of measures to prevent and address homelessness (such as 1,500 rapid-build units, higher rates of rental subsidy for those exiting homelessness, and an expanded tenancy protection service in urban areas) and to address aspects of housing precarity in the private rented and owner occupied tenures. The explanation for this high political salience of homelessness lies, as noted above, in the spread of housing precarity amongst low-income households who are private renters or are in mortgage arrears, and the increase in family homelessness, particularly in the Dublin region.

Scotland (as part of the United Kingdom) was subject to sweeping austerity measures in the post 2008 period, with an emphasis on the reduction of the public sector deficit through cuts in public expenditure which fell disproportionately on the poor and the young (Institute for Policy Research, 2015). The Scottish homelessness policy response was to promote homelessness prevention (known as Housing Options) alongside the existing legal safety net, acknowledging that it would not be feasible to 'build a way out of homelessness'. Homelessness prevention guidance was launched in 2009 with Scottish Government funding from 2010 to promote joint working 
and sharing of practice across local authorities. Policy change was governed through a joint stakeholder group with representation from central and local government (housing, health and social care services), third sector service providers and homelessness charities. From 2013 this Homelessness Prevention and Strategy Group had an explicit brief to further embed homelessness prevention activity in Scotland (Scottish Government, 2015b). The Housing (Scotland) Act 2014 gave greater discretion to social landlords in terms of who should be prioritised for housing, but also announced the abolition of the 'Right to Buy' in order to preserve the remaining social housing stock. The Private Housing (Tenancies) (Scotland) Act 2016 provided for modernisation of the terms of private rented tenancies in parallel with policy goals to better support access to private renting for lower income households. Further Housing Options guidance was issued in 2016 (Scottish Government, 2016b). Scottish Government (2016a) homelessness statistics reported a continuing fall in homelessness applications in the post-2008 period. However, this was acknowledged as reflecting the impact of housing options/homelessness prevention strategies rather than changes in the structural drivers of homelessness. It was further acknowledged that the reduction in homelessness had already slowed to a point where the impact of prevention was unlikely to lead to further large reductions in homelessness applications, with two thirds of homeless applicants having first been through the housing options service (Scottish Government, 2015a, 2015b).

Longitudinal, independent analysis of the impact on homelessness of economic and policy developments (from a baseline in 2012) concluded that Scotland faced a slow pace of economic recovery combined with the impact of welfare and housing reform (Fitzpatrick et al., 2015), but Scotland retained the most ambitious homelessness legislation in the UK. Enumerated homelessness actually peaked in 2005/6 ahead of the GFC, as Scotland expanded its homelessness safety net up to 2012. This was followed by a marked downward trend in the 5 years up to 2015, acknowledged to be a result of homelessness prevention and despite wider austerity measures (Fitzpatrick et al., 2015; Scottish Government, 2015a, 2015b). Anderson and Serpa (2013) interpreted these trends as a 'blurring' of homelessness policy in the austerity period, and the Housing Options approach was also reviewed critically by the Scottish Housing Regulator (2014) for lack of clarity in relation to the statutory homelessness system. Research by Mackie and Thomas (2015) revealed that $80 \%$ of approaches to homelessness prevention services were from single people, who remained more likely than families to become homeless, to experience drug/alcohol dependency or mental health issues, to be temporarily accommodated in hostels or B\&Bs, and to wait longer for settled accommodation.

While homelessness has been an important policy issue in Norway for more than a decade, the number of homeless people saw a slight but steady increase in the post-2008 period. The Norwegian government had previously implemented two national schemes to prevent and combat homelessness. Project Homeless (2001-2004), included only the largest cities while Pathway to a Permanent Home (2005-2007) was implemented nationwide, and the subsequent national homeless census for 2008 coincided with the onset of the GFC. Although Norway was largely shielded from the effects of the crisis, some financial uncertainty was experienced in the housing market. People became more hesitant to buy housing, and so some of those in cohorts expected to move into homeownership lingered in the rental sector, thus 'occupying' dwellings that under other conditions would have been available for vulnerable households (Dyb, Helgesen, \& Johannessen, 2008). This interpretation would explain why homelessness increased despite a nationwide program to combat homelessness, although pressures in the sparse municipal rental sector and similarly limited private rental sector also contributed. The national strategy had set some quite ambitious targets for combating homelessness, and evaluation found that the single most important explanation for not reaching those targets was shortage of available housing in the municipalities (Dyb et al., 2008). Since 2008, Norway has not had a homeless strategy or scheme. From around 2010 the Housing Bank coordinated the 'Social housing development program' in which selected municipalities facing considerable social housing challenges (including homelessness) were invited to cooperate with the Housing Bank. Contractually, the Housing Bank provided funding and assistance, while municipalities committed to working towards specific objectives (defined by the municipalities or with assistance from researchers/consultants). Evaluation (utilising 'soft' measurements) demonstrated that the participating municipalities implemented the programme in accordance with the contracts (Grønningsæter, Becken, Bakkeli, Klingenberg, \& Strand, 2015), and the homeless census due in November 2016 was anticipated to provide a further measure of the effects of the programme. The 'Social housing development programme' was winding up during this research with the 'Housing for welfare' strategy being rolled out (2015-2020). Homelessness and housing exclusion were increasingly recognised as "wicked problems" in Norway, requiring involvement of all national welfare institutions and other stakeholders. 'Housing for welfare' was supported by five Ministries and was more far-reaching than the former scheme (Housing for Welfare, 2014). Among priority groups were families with children experiencing homelessness or at risk of homelessness, and refugees with a residence permit waiting in a refugee centre for settlement. The most visible change in homelessness and social housing policy since 2008 was to a broader approach, additionally including households in precarious housing situations and linking homelessness policy to anti-poverty and labour market policies. However, the Ministry responsible for housing and the Housing Bank were still the main stakeholders for the homelessness policies. 
The evidence in this section has raised some further challenges in interpreting post-2008 homelessness policy change in terms of direct responses to the GFC and to austerity politics. The comparative analysis is further developed below (section 5).

\section{Comparative Analysis}

In this section, we refine our comparative analysis of homelessness policy change in the 'former arc of prosperity' drawing on our analytical model (Table 1) and the empirical evidence presented from the three case study countries. We consider in what ways politics and institu- tional settings may have mediated the homelessness policy responses, and whether conceptualisation of homelessness and policies have exhibited greater divergence or not in the period since 2008.

In Ireland, the national homelessness strategy published on the eve of the GFC embraced a housing-led approach to tackling homelessness, albeit that a heavy reliance was now placed on the private rented sector as a housing exit. Moreover, a preventative dimension also featured strongly in the strategy. The impact of the GFC (and the bursting of the property price bubble) led to a lagged impact on the scale and nature of homelessness, manifesting as a steady increase in the numbers of fam-

Table 1. Continuities and Changes in aspects of homelessness in post-2008 Ireland, Scotland and Norway. Source: authors.

\begin{tabular}{|c|c|c|c|}
\hline Aspects of Homelessness & Ireland & Scotland & Norway \\
\hline $\begin{array}{l}\text { Nature and scale of } \\
\text { homelessness }\end{array}$ & $\begin{array}{l}\text { Increase in family } \\
\text { homelessness due to } \\
\text { structural (housing and } \\
\text { economic) factors. }\end{array}$ & $\begin{array}{l}\text { Decrease in homelessness } \\
\text { explained by prevention } \\
\text { strategy despite austerity; } \\
\text { continuity in profile of } \\
\text { homeless population. }\end{array}$ & $\begin{array}{l}\text { Minimal increase in the } \\
\text { relative number of } \\
\text { homeless persons. } \\
\text { Considerable increase in } \\
\text { family homelessness. }\end{array}$ \\
\hline $\begin{array}{l}\text { New/updated } \\
\text { strategy }\end{array}$ & $\begin{array}{l}\text { Yes: a number of policy and } \\
\text { legislative changes: } \\
\text { Housing Act 2009, } \\
\text { Homeless Policy Statement } \\
\text { 2013, Implementation Plan } \\
\text { 2014, Rebuilding Ireland } \\
2016 .\end{array}$ & $\begin{array}{l}\text { Continuation of } \\
\text { strengthening of legislative } \\
\text { frame work through GFC } \\
\text { (2003-2012), combined } \\
\text { with parallel strategy to } \\
\text { enhance homelessness } \\
\text { prevention though Housing } \\
\text { Options services from } \\
2009 \text {. }\end{array}$ & $\begin{array}{l}\text { Continuous programmes } \\
\text { since } 2000 . \text { Post 2008: } \\
\text { Homelessness is part of a } \\
\text { wider programme } \\
\text { addressing social housing } \\
\text { and services. }\end{array}$ \\
\hline Objectives & $\begin{array}{l}\text { The target of eliminating } \\
\text { homelessness remained, } \\
\text { but the end-date was } \\
\text { pushed back from } 2010 \text { to } \\
2016 .\end{array}$ & $\begin{array}{l}\text { From 2009, aim to prevent } \\
\text { homelessness where } \\
\text { possible (e.g. earlier } \\
\text { intervention through } \\
\text { Housing Options), while } \\
\text { sustaining existing legal } \\
\text { safety net. }\end{array}$ & $\begin{array}{l}\text { Preventing and curbing } \\
\text { homelessness. Soft } \\
\text { measures: financial project } \\
\text { support, development of } \\
\text { qualifications. No changes } \\
\text { post } 2008 \text {. }\end{array}$ \\
\hline Institutions & $\begin{array}{l}\text { Establishment of Regional } \\
\text { Homeless Fora. }\end{array}$ & $\begin{array}{l}\text { National: multi-stakeholder } \\
\text { Homeless Prevention and } \\
\text { Strategy Group. } \\
\text { Local: local authorities lead } \\
\text { partnerships with other } \\
\text { statutory and voluntary } \\
\text { agencies. }\end{array}$ & $\begin{array}{l}\text { National: } \\
\text { Multi-stakeholder } \\
\text { programmes, the Housing } \\
\text { Bank is the coordinating } \\
\text { agency. } \\
\text { Local: Social services are } \\
\text { the main stakeholder. }\end{array}$ \\
\hline $\begin{array}{l}\text { Basic } \\
\text { idea/philosophy }\end{array}$ & $\begin{array}{l}\text { Deepening of housing-led } \\
\text { approach to what was } \\
\text { conceived as a small } \\
\text { number of 'chronic' } \\
\text { homeless persons with } \\
\text { individual-level deficits. }\end{array}$ & $\begin{array}{l}\text { Housing-led since 1977, } \\
\text { legal framework } \\
\text { strengthened in } 2001 \text { and } \\
2003 \text { Acts. } \\
\text { Increased recognition of } \\
\text { need for improved joint } \\
\text { working with health, care } \\
\text { and support services in } \\
21^{\text {st }} \text { century, continued } \\
\text { post-2008. }\end{array}$ & $\begin{array}{l}\text { Housing led from the first } \\
\text { programme in } 2000 \text {. No } \\
\text { changes post } 2008 \text {. }\end{array}$ \\
\hline
\end{tabular}


ilies in emergency accommodation, with the issue gaining high political salience from 2014. A new social housing strategy continued to emphasise the role of the private rented sector as an accommodation solution, despite rising rents and lack of participation of private landlords. A series of rather ad hoc policy responses to what is now widely deemed to be a homelessness crisis has been outlined by the new 'partnership government'. In retrospect, the ambition of the 2008 target of eliminating homelessness was based on the assumption of rooflessness and houselessness as (a) caused by individual level deficits and (b) as generating a small and stable number of 'chronic' homeless persons.

Scotland demonstrated 'positive path dependency' in the period immediately following the introduction of devolved government in 1999 when its 'rational' review of homelessness policy (Simon, 1959) through a Homelessness Task Force resulted in a strengthening of the longstanding legal framework at a time of economic prosperity and political confidence (Anderson, 2009). Post 2008, neither political change nor economic crisis produced sufficient pressure to undo the strongly inclusive policy and legislation in place since 2003. Rather, these embedded structures were more subtly affected by welfare reform, constraints on social housebuilding and a switch of emphasis to the 'soft policy' options of homelessness prevention and housing advice. Perhaps unusually, trends in homelessness reflected policy change more than economics. Homelessness applications increased during the period of prosperity (20002006) as the legislative framework was expanded and showed a modest decline during 2006-2012 as the expanded framework bedded down and the housing options/homelessness prevention services were introduced. Homelessness reduced significantly during 20112015 with the increased push to housing options services, but this may already have reached its full potential by 2016 . While homelessness policy and practice may have mitigated some of the potentially worst effects of the financial crisis, avoiding a surge in homelessness post 2008, homelessness remained at a high level compared to Ireland and Norway, and other dimensions of hardship increased, such as time in temporary accommodation and use of new services such as food banks in the austerity period.

For Norway, the notion of path dependency demonstrates points of change and continuity in homelessness policy with the continuing presence of the Housing Bank as the main player. The transformation from a bank, although state owned with a social profile (it was first and formerly a finance institution), into a state welfare agency was not an obvious outcome of earlier rapid changes in housing policy. On the other hand, downsizing of the Housing Bank's traditional responsibilities coincided with an increased and renewed interest in homelessness research and policy. Unlike Ireland and Scotland, the definition of homelessness is not institutionally embedded in the housing legislation in Norway. The right to housing holds a weak position in the social welfare legislation phrased as the social services' duty to assist with acquiring a permanent dwelling, whereas the responsibility for homeless policy and intervention programmes is assigned to the housing sector at the national level. Responsibility of homelessness policy placed on the housing authorities represents a strong incentive for maintaining housing as part of the homelessness solution and from the very first national programme launched in 2001, a housing led homelessness policy became a principal objective. Distinct from the financial crisis, it is hard to detect any austerity policy in the homelessness sector from 2008 to 2016.

Overall, our comparative analysis suggests few distinctive characteristics of homelessness policy according to Esping-Andersen's welfare regimes. This conclusion differs somewhat from that of a comparative analysis of homeless strategies in five liberal welfare states (Ireland, England, Northern Ireland, Scotland and Wales) and four social democratic welfare states (Denmark, Finland, Norway and Sweden), in the period 2005 to 2011 (Benjaminsen et al., 2009). The 2009 analysis was based on a review of homeless strategy documents and not on the implementation of the strategies. All the strategies shared some common objectives, like ending street homelessness, reducing stays in shelters, providing longterm or permanent accommodation and providing individualised services and support. In the five liberal welfare states, a statutory definition of homelessness embedded in the housing legislation was evident in the strategy documents. Generally, the link to housing policy was less evident in the homelessness strategies of the social democratic welfare states. As demonstrated here, Norwegian homelessness policy shares a strong linkage to housing policy with its two liberal counterparts, although the ties to the housing system have different institutional sources; the Housing Bank in Norway and the legal framework in Ireland and Scotland.

Thus, while in Ireland and Scotland the concept of homelessness is shaped by the legal framework, in Norway the definition derives from research and policy purposes. The definition of homelessness in Ireland appears more elastic than that of Norway, with Scotland embracing the broadest interpretation of homelessness. In both Ireland and Scotland municipalities have some discretionary authority in their interpretation of the respective legal frameworks and national policies. This allows for a certain flexibility in assessing homelessness, but overall interpretation is driven at national level, albeit in partnership with municipalities. The Norwegian definition has been developed from homelessness censuses over a period of 20 years, and conformity to the definition throughout the censuses is an important part of maintaining the time series of homelessness data. Looking past the formal definitions, all three countries apply concepts of homelessness with extensive room for political priorities and shift of focus between different homeless subgroups. 
In their analysis Benjaminsen, Dyb, \& O'Sullivan (2009) observed that the strategy documents in the liberal cluster of welfare states were extremely detailed. The authors noted that this is was likely to reflect the relationship between central and local authorities, which left limited room for the local authorities to make their own plans. In contrast, the relatively greater autonomy of the municipalities in the social democratic welfare states afforded them far-reaching scope for local adaptation of the national strategy. The analysis in the present article nuances this conclusion from the homelessness strategy analysis. In Ireland and Norway, municipalities have a rather wider autonomy to prioritise between groups and shape a local service provision, compared to Scotland, where local autonomy in homelessness policy is more limited, although evidence does indicate some local discretion in practice. In Ireland, however, the centre has asserted greater control since 2008 , with more stringent reporting requirements re process and outcome imposed on local authorities. Moreover, in all three countries, it is acknowledged that the high proportion of persons with multiple needs in the homeless population requires cooperation and coordination between housing, health, social services, child welfare and criminal justice services. The increasing effectiveness of their incorporation into national homelessness strategies and implementation demonstrates a gradual shifting of institutional embeddedness linked to the long term trend to better joined-up governance across public services.

The voluntary sector has traditionally played an important part in service provision to the poorest and most in need, including homeless households. Its size and the role differs considerably between Ireland, Norway and Scotland. Among the three case study countries, Ireland stands out as having a particularly influential voluntary sector in the homelessness field, with Norway and Scotland more equal regarding the role of homelessness voluntary organisations as partners of local authorities. A common characteristic of the present position of the voluntary sector in the North European countries is increased reliance on public funding, implying a degree of regulation of standards of service provision. However, the voluntary sector can still maintain some distance from statutory authorities, and define themselves as advocates for specific groups. Increasing dependence on public funding will require voluntary organisations to follow national and municipal priorities regarding homelessness groups and the orientation of public programmes, as public budgets reflect policy priorities.

Defining and redefining the concept of homelessness, and making decisions about who is entitled to support and who is not, is a way of governing homelessness policy. This observation was made by Sahlin (2004) analysing Swedish homeless policy more than ten years ago. One of the conclusions from the comparative analyses in this article is that, beyond diverging legal and/or research driven definitions of homelessness, governments in all three countries exercise power to define and re- define who and which groups are a focus of homelessness policy in any given period. The voluntary sector often represents one or several voices in the homelessness discourse, which may produce some challenge to government programmes and policy along with service user organisations. These voluntary and service user organisations are present in all three countries, but appear to have a particularly strong voice in the Irish case.

Although there are differences across the three countries in the conceptualisation and measurement of homelessness, it is evident that homelessness remains a persistent problem across Ireland, Scotland and Norway. Our analysis supports the path dependency approach that 'history matters' in housing policy analysis (also Malpass, 2000, 2005). Despite institutional inertia and converging processes at European level, the analysis here also suggests that national 'politics' matters-as policies can defend inclusive, housing led approaches to homelessness, even in an era of neoliberal political convergence, economic crisis and austerity politics.

\section{Conclusion}

Despite progress made by FEANTSA and the introduction of ETHOS (European Typology of Homelessness and Housing Exclusion), comparing the exact number of homeless persons between different countries is still a considerable challenge. However, a growing body of comparative policy reviews, analysis and, to some extent, research in the field of homelessness has contributed to increased mutual understanding of concepts and a mutual language for comparison across countries and welfare state regimes. Due to unsystematic differences in the housing systems without any obvious pattern, comparative research and analysis has been hugely challenging in the field of housing (e.g. Crook \& Kemp, 2014; Oxley, 2001; Stephens, 2016). To some extent, these challenges of conducting comparative research in housing also affect the homelessness field. At the end of the day, regardless of the definition of homelessness and whether policy is primarily embedded in housing or welfare policies, housing is essential in order to end or alleviate homelessness. Definitions, discretions and prioritising thus still govern who should have access to social or subsidised affordable housing and who has less priority or is excluded from the 'deserving' groups.

Our analysis of Ireland, Scotland and Norway indicated that Esping-Andersen's notion of welfare state regimes is not the most fruitful approach to comparing homeless policy among a small group of countries that share some common features regardless of their welfare regimes. Nonetheless, welfare state regimes continue to offer researchers an attractive departure point for comparative analysis, despite longstanding acknowledgement that housing does not fit the typology at all well. Kemeny (2001) emphasised the difference between the welfare regimes and the welfare systems produced within the regimes. National welfare systems are not a 
static reflection of a specific welfare regime. The related approach of institutionalism led us to consider the significance of path dependency in relation to the institutions which underpin homelessness policy and practice in our three countries, the opportunities for change and the constraints which determine continuity in approaches to homelessness. This approach was fruitful in confirming strong formal linkages to housing policy in the homelessness strategies of all the three countries, and a considerable degree of resilience in relation to housing-led solutions to homelessness through varying political and economic pressures in the three countries since the GFC. Our analysis here points in the direction of curbing the use of the welfare state regimes as a comparative parameter and reconsidering the potential of institutional analysis as an alternative. Further empirical research across a larger number of countries and welfare regimes would enable more rigorous testing of this conclusion, and such research would require to be longitudinal in order to test for continuity or change in path dependency of housing and homelessness policies in relation to wider welfare structures.

\section{Acknowledgements}

The authors are grateful to colleagues who have commented on earlier versions of this paper presented at international conferences, and to the two anonymous referees who provided valuable comments on the earlier version submitted for publication.

\section{Conflict of Interests}

The authors declare no conflict of interests.

\section{References}

Anderson, I. (2004). Housing, homelessness and the welfare state in the UK. European Journal of Housing Policy, 4(3), 369-389.

Anderson, I. (2009). Homelessness policy in Scotland: A complete safety net by 2012 ? In S. Fitzpatrick, D. Quilgars, \& N. Pleace (Eds.), Homelessness in the UK: Problems and solutions (pp. 107-124). Coventry: Chartered Institute of Housing.

Anderson, I., Dyb, E., \& Finnerty, J. (2008). Homelessness policy and housing options in three European countries: Ireland, Scotland and Norway. In D. Downey (Ed.), Perspectives on Irish Homelessness: Past, present and future (pp. 44-55). Dublin: Homeless Agency.

Anderson, I., \& Serpa, S. (2013) The right to settled accommodation for homeless people in Scotland: A triumph of rational policy making? European Journal of Homelessness, 7(1), 13-39. Retrieved from http:// www.feantsaresearch.org/spip.php?article234\&lang =en

Anderson, I., \& Ytrehus, S. (2012). Reconceptualising ap- proaches to meeting the health needs of homeless people. Journal of Social Policy, 41(3), 551-568.

Annaniassen, E. (2006). Norge-det socialdemokratiska ägarlandet (Norway-the social democratic homeownership country). In B. Bengtsson, E. Annaniassen, L. Jensen, H. Ruonavaara, \& R. J. Sveinsson (Eds.), Varför så olika? Nordisk bostadspolitik i jämförande historisk ljus [Why so divergent? Nordic housing policy in a historical comparative light] (pp. 159-218). Malmö: Égalité.

Baptista, I., \& O'Sullivan, E. (2008). The role of the state in developing homeless strategies: Portugal and Ireland in comparative perspective. European Journal of Homelessness, 2, 23-41.

Beer, A. (2012). Housing governance. International Encyclopedia of Housing and Home, 3, 497-501.

Bengtsson, B., Annaniassen, E., Jensen, L., Ruonavaara, H., \& Sveinsson, J. R. (2006). Varför så olika? Nordisk bostadspolitik i jämförande historisk ljus [Why so divergent? Nordic housing policy in a historical comparative light]. Malmö: Égalité.

Bengtsson, B., \& Ruonavaara, H. (2010). Introduction to a special issue on path dependence in housing. Housing, Theory and Society, 27(3), 193-203.

Benjaminsen, L., Dyb, E., \& O'Sullivan, E. (2009). The governance of homelessness in liberal and social democratic welfare regimes. European Journal of Homelessness, 3, 23-51.

Benjaminsen, L., \& Lauritzen, H. (2015). Hjemløshed $i$ Danmark 2015. National kortlægning [Homelessness in Denmark 2015. National survey] (Report 15:35). Copenhagen: SFI.

Bergin, E., Lawless, K., Lalor, T., \& Pym, M. (2005). Settlement first. Dublin: Simon Communities of Ireland.

Cork Simon Community. (2016). Rough sleeping in Cork August 2016. Retrieved from https://www. corksimon.ie/about-homelessness/homeless-watch

Crook, T., \& Kemp, P. A. (2014). Introduction. In T. Crook \& P. A. Kemp (Eds.), Private rental housing. Comparative Perspectives (pp. 1-26). Cheltenham: Edward Elgar Publishing Limited.

Deacon, B. (2000). Eastern European welfare states: The impact of the politics of globalization. Journal of European Social Policy, 10(2), 146-161.

DECLG. (2013). Homelessness policy statement. Dublin: DoECLG.

DECLG. (2014). Social Housing Strategy 2020. Dublin: Stationery Office.

DECLG. (2016). Homelessness report August 2016. Dublin: DoECLG. Retrieved from http://www.housing. gov.ie/sites/default/files/publications/files/homeless report_-_august_2016.pdf

DEHLG. (2008a). The way home-A strategy to address adult homelessness in Ireland 2008-2013. Dublin: Stationery Office.

DEHLG. (2008b). Annual housing statistics bulletin 2008. Retrieved from www.environ.ie/en/Publications/ StatisticsandRegularPublications/HousingStatistics/ 
FileDownLoad,20957,en.pdf

DiMaggio, P. J., \& Powell, W. W. (1991). The iron cage revisited. Institutional isomorphism and collective rationality in organization fields. In W. W. Powell \& P. J. DiMaggio (Eds.), The new institutionalism in organizational analysis (pp. 63-82). Chicago: The University of Chicago Press.

DRHE. (2016). Access to homeless services and move on to tenancies Q1 2016. Dublin: DRHE.

Dukelow, F. (2016). The Irish welfare state in the twentyfirst century: Challenges and change. In M. P. Murphy \& F. Dukelow (Eds.), The Irish welfare state in the twenty-first century: Challenges and change (Ch. 14). Basingstoke: Palgrave Macmillan.

Dyb, E., \& Johannessen, K. (2013). Bostedsløse i Norge 2012-En kartlegging [Homelessness in Norway 2012-A survey]. NIBR-report 2013:5. Oslo: The Urban and Regional Research Institute. Retrieved from http://biblioteket.husbanken.no/arkiv/dok/Sum/Bos tedsloseNorge2012_eng.pdf

Dyb, E., Helgesen, M. K., \& Johannessen, K. (2008). På vei til egen bolig. Evaluering av nasjonal strategi for å forebygge og bekjempe bostedsløshet [The pathway to a permanent home. Evaluation of the national strategy to prevent and counteract homelessness 2005-2007] (NIBR-report 2008:15). Oslo: The Urban and Regional Research Institute. Retrieved from http://www.hioa.no/extension/hioa/ design/hioa/images/nibr/files/filer/2008-15.pdf

Edgar, B. (2009). European review of statistics on homelessness. Brussels: FEANTSA.

Esping-Andersen, G. (1990). The three worlds of welfare capitalism. Cambridge: Polity Press.

FEANTSA (2016). Ethos typology on homelessness and housing exclusion. Brussels: FEANTSA. Retrieved from http://www.feantsa.org/spip.php?article120

Ferrera, M. (1996). The 'southern model' of welfare in social Europe. Journal of European Social Policy, 6(1), 17-37. doi:10.1177/095892879600600102

Finnerty, J. (2002). Homes for the working classes? Irish public house-building cycles, 1947-2002. Saothar: Journal of the Irish Labour History Society, 27, 65-71.

Finnerty, J. (2014a). Ending adult homelessness in an age of austerity-Neither low-hanging fruit nor systemic change. Paper presented at WELPHASE workshop, European Network of Housing Research 2014 conference, Edinburgh, July.

Finnerty, J. (2014b). Preventing and ending homelessness for adults with mental health disabilities in Ireland: Realities and aspirations. In C. Clarke (Ed.), Homelessness. Prevalence, impact of social factors and mental health challenges (pp. 1-16). New York: NOVA.

Finnerty, J., \& O'Connell, C. (2014a). 50 years of the social housing 'offer' in Ireland: The casualisation thesis examined. In L. Sirr (Ed.), Public and private renting in Ireland (pp. 170-181). Dublin: IPA.

Finnerty, J., \& O'Connell, C. (2014b). Housing ladders and snakes: An examination of changing residential tenure trajectories in the Republic of Ireland. In P. Kenna (Ed.), Contemporary housing issues in a globalized world (pp. 251-266). Farnham: Ashgate.

Finnerty, J., O'Connell, C., \& O'Sullivan, S. (2016). The changing regime of social housing policy and provision. In M. P. Murphy \& F. Dukelow (Eds.), The Irish welfare state in the twenty-first century: Challenges and change (Ch. 11). Basingstoke: Palgrave Macmillan.

Fitzpatrick, S., \& Stephens, M. (2014). Welfare regimes, social values and homelessness: Comparing responses to marginalised groups in six European countries. Housing Studies, 29(2), 215-234.

Fitzpatrick, S., Pawson, H., Bramley, G., Wilcox, S., \& Watts, B. (2015). The homelessness monitor: Scotland. London: Crisis.

Gal, J. (2010). Is there an extended family of Mediterranean welfare states? Journal of European Social Policy, 20(4), 283-300.

Gosme, L. (2014). Key steps towards a European Union homelessness policy. Journal of European Social Policy, 24(3), 289-299.

Gosme, L., \& Anderson, I. (2015). International learning as a driver of innovation in local-level policy making: Achievements and challenges from peer review of homelessness policies. European Journal of Homelessness, 9(1), 37-59. Retrieved from http:// www.feantsaresearch.org/spip.php?article377

Government of Ireland. (2016). Rebuilding Ireland: Action plan on housing and homelessness. Retrieved from http://rebuildingireland.ie

Grønningsæter, A. B., Becken, L-E., Bakkeli, V., Klingenberg, S., \& Strand, A. H. (2014). Evaluering av Husbankens kommunesatsing [Evaluation of The Housing Bank's municipal program]. Oslo: Fafo. Retrieved from http://fafo.no/images/pub/2014/20398.pdf

Hoekstra, J. (2010). Divergence in European welfare and housing systems (Doctoral dissertation). Delft University of Technology. Amsterdam: IOS Press BV.

Housing for Welfare (2014). National strategy for housing and support services (2014-2020). Oslo: The Norwegian Government. Retrieved from https:// www.regjeringen.no/globalassets/upload/kmd/boby/ housing_for_welfare_national_strategy_for_housing _and_support_services_2014_2020.pdf

Institute for Policy Research. (2015). Alternatives to austerity. Bath: University of Bath.

Irving-Clarke, Y. (2016). Supporting people-How did we get here and what does it mean for the future? (Doctoral dissertation). De Montfort University.

Kemeny, J. (1995). From public housing to the social market: Rental policy strategies in comparative perspective. London: Routledge.

Kemeny, J. (2001). Comparative housing and welfare: Theorising the relationship. Journal of Housing and the Built Environment, 16, 53-70.

Kenna, P. (2011). Housing law, policy and practice in Ire- 
land. Dublin: Clarus Press.

Lupton, R., Burchardt, T., Hills, J., Stewart, K., \& Vizard, P. (2016). Social policy in a cold climate: Policies and their consequences since the crisis. Bristol: Policy Press.

Mackie, P., \& Thomas. I. (2015). Single homelessness in Scotland. London: Crisis.

Mahoney, J. (2000). Path dependence in historical sociology. Theory and Society, 29(4), 507-548.

Malpass, P. (2000). Housing associations and housing policy. Basingstoke: Palgrave Macmillan.

Malpass, P. (2005). Housing and the welfare state. The development of housing policy in Britain. Basingstoke: Palgrave Macmillan.

McKee, K., Muir, J., \& Moore, T. (2016). Housing policy in the UK: The importance of spatial nuance. Housing Studies. doi:10.1080/02673037.2016.1181722

Morelli, C., \& Seaman, P. (2012). Income and wealth inequalities in Scotland since 1997. In G. Mooney \& G. Scott (Eds.), Social justice and public policy in Scotland (pp. 43-60). Bristol: Policy Press.

North, D. C. (1990). Institutions, institutional change and economic performance. Political economy of institutions and decisions. New York: Cambridge University Press

O'Reilly, F., Barror, S., Hannigan, A., Scriver, S., Ruane, L., MacFarlane, A., \& O'Carroll, A. (2015). Homelessness: An unhealthy state. Health status, risk behaviours and service utilisation among homeless people in two Irish cities. Dublin: The Partnership for Health Equity.

Oxley, M. (2001). Meaning, science, context and confusion in comparative housing research. Journal of Housing and the Built Environment, 16, 89-106.

Pisani-Ferry, J., Sapir, A., \& Wolff, G. (2013). EU-IMF assistance to euro-area countries: An early assessment. Brussels: Breugel.

Powell, R., Dunning, R., Ferrari, E., \& McKee, K. (2015). Affordable housing need in Scotland (Summary Report). Edinburgh: Shelter Scotland.

Sahlin, I. (2004). Central state and homelessness policies in Sweden: New ways of governing. European Journal of Housing Policy, 4(3), 345-367.

Sainsbury, D. (1999). Gender, policy regimes, and politics. In D. Sainsbury (Ed.), Gender and welfare states regimes (pp. 248-260). Oxford: University Press.

Scottish Government. (2007). Principles and priorities: The Government's programme for Scotland. Edinburgh: Scottish Government. Retrieved from http:// www.gov.scot/Resource/Doc/197113/0052743.pdf

Scottish Government (2008). Operation of the homeless persons legislation in Scotland 2007-8. Edinburgh: Scottish Government.
Scottish Government (2015a). Operation of the homeless persons legislation in Scotland 2014-15. Edinburgh: Scottish Government.

Scottish Government (2015b). Housing options (PREVENT 1) statistics in Scotland 2014-15. Edinburgh: Scottish Government. Retrieved from http://www. gov.scot/Topics/Statistics/Browse/Housing-Regenera tion/RefTables/PREVENT1to31Mar15

Scottish Government (2016a). Operation of the homeless persons legislation in Scotland 2015-16. Edinburgh: Scottish Government.

Scottish Government (2016b). Housing options guidance. Edinburgh: Scottish Government.

Scottish Housing Regulator (2014). Housing options in Scotland: A thematic enquiry. Glasgow: Scottish Housing Regulator.

Simon, H. (1959). Theories of decision-making in economics and behavioural science. American Economic Review, 49(3), 253-283.

Stams $\varnothing$, M. A. (2009). Housing and the welfare state in Norway. Scandinavian Political Studies, 32(2), 195220. doi:10.1111/j.1467-9477.2008.00223.x

Stams $\varnothing$, M. A. (2014). Norway. In T. Crook \& P. A. Kemp (Eds.), Private rental housing. Comparative perspectives (pp. 125-147). Cheltenham: Edward Elgar Publishing Limited.

Stephens, M. (2016). Using Esping-Andersen and Kemeny's welfare and housing regimes in comparative housing research. Critical Housing Analysis, 3(1), 1929.

Stephens, M., Fitzpatrick, S., Elsinga, M., van Steen, G., \& Chzhen, Y. (2010). Study on housing exclusion: Welfare policies, housing provision and labour markets. Brussels: European Commission. Retrieved from https://pureapps2.hw.ac.uk/portal/files/4727289/ housing_exclusion_1_.pdf

Torgersen, U. (1987). Housing: The wobbly pillar of the welfare state. In B. Turner, J. Kemeny, \& L. J. Lundqvist (Eds.), Between state and market: Housing in the postindustrial era (pp. 116-126). Stockholm: Almqvist \& Wiksell International.

United Nations (2015). Classification of countries by major area and region of the world (World population prospects: The 2015 Revision). New York: United Nations Department of Economic and Social Affairs/Population Division.

Walsh, K., \& Harvey, B. (2015). Family experiences of pathways into homelessness. Dublin: Housing Agency.

Yin, R. K. (1994). Case study research. Design and methods. Thousand Oaks: Sage Publications. 


\section{About the Authors}

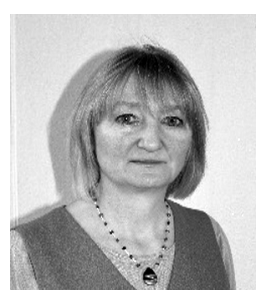

Isobel Anderson is Chair in Housing Studies and Associate Dean (Research) in the Faculty of Social Sciences at the University of Stirling, Scotland. She was founder/co-ordinator of the working group on Welfare Policy, Homelessness and Social Exclusion within the European Network for Housing Research (2003-2013) and is currently a Member of the International Advisory Committee of the European Journal of Homelessness and a board member of Homeless Action Scotland.

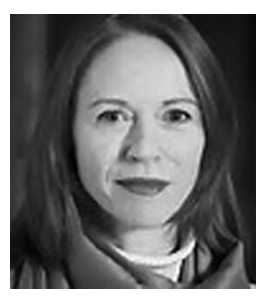

Evelyn Dyb is Research Professor at the Urban and Regional Research Institute, Oslo and Akershus University College, Norway. Her prime research interest is in housing and welfare. She is a member of the International Advisory Committee of the European Journal of Homelessness, one of the coordinators of the Welfare Policy, Homelessness and Social Exclusion within the European Network for Housing Research and national coordinator of the Nordic Network of Homelessness Research.

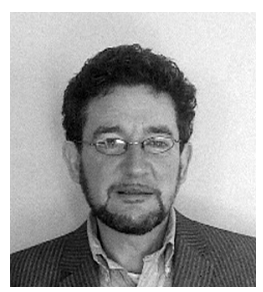

Joe Finnerty is Course Director of the Higher Diploma in Social Policy in the School of Applied Social Studies, University College Cork. His research interests are principally in the areas of housing and homelessness, poverty and social exclusion, and quantitative research methods. He is a coordinator of the Welfare Policy, Homelessness and Social Exclusion working group of the European Network of Housing Research, is Ireland correspondent for the European Observatory on Homelessness, and sits on the Cork Kerry Youth Out of Home Forum. 